\title{
The role of tropical dry forests for biodiversity, carbon and water conservation in the neotropics: lessons learned and opportunities for its sustainable management
}

\author{
Carlos Portillo-Quintero • Arturo Sanchez-Azofeifa • \\ Julio Calvo-Alvarado • Mauricio Quesada • \\ Mario Marcos do Espirito Santo
}

Received: 25 April 2014/Accepted: 22 August 2014/Published online: 6 September 2014

(C) Springer-Verlag Berlin Heidelberg 2014

\begin{abstract}
In this paper, we provide a comprehensive evaluation of the current regional literature associated with tropical dry forest (TDF) along three main axes: biodiversity, carbon and water conservation in the neotropics. Our analysis provides three key findings: (1) from the biodiversity point of view, we document that high degrees of endemism, diversity of plant life forms and ecophysiological types as key elements for their conservation across the Americas, (2) from the carbon storage point of view, we found that if the world's TDFs were restored they whole ecosystem would comprise $22 P_{\mathrm{g}}$ of carbon in aboveground biomass. In the Americas alone, TDF restoration could potentially add $8 P_{\mathrm{g}}$ of carbon to the potential total ecosystem carbon stock, (3) we found that at least $66 \%$ of water reservoirs in the neotropics are located within dry forest ecoregions; therefore, the conservation of
\end{abstract}

Editor: Wolfgang Cramer.

C. Portillo-Quintero · A. Sanchez-Azofeifa $(\square)$

Center for Earth Observation Sciences (CEOS), Department of

Earth and Atmospheric Sciences, University of Alberta,

Edmonton, AB T6G 2E3, Canada

e-mail: arturo.sanchez@ualberta.ca

J. Calvo-Alvarado

Escuela de Ingenieria Forestal, Instituto Tecnológico de Costa

Rica, Cartago, Cartago, Costa Rica

M. Quesada

Centro de Investigaciones en Ecosistemas (CIECO), Universidad Nacional Autónoma de México (UNAM), Morelia, Michoacan, Mexico

M. M. do Espirito Santo

Departamento de Biologia Geral/CCBS, Universidade Estadual de Montes Claros, CP 126, Montes Claros, MG CEP 39401-089, Brazil the quality of freshwater sources for human consumption in the neotropics is directly dependent on the sustainable management of TDF-dominated landscapes. In this paper, we stress that advocacy for conservation and sustainable management of TDF will benefit from integrating it's value in biophysical terms (e.g. carbon, biodiversity) with key ecosystem services and uses (e.g. its impact on hydrological dynamics and its potential for fostering ecotourism initiatives and entrepreneurship). By doing this, support and awareness could be wider and more effective in the long term, especially from national and local communities.

Keywords Neotropical dry forests - Conservation . Biodiversity $\cdot$ Ecosystem services

\section{Introduction}

The tropical dry forest (TDF) biome has held a close relation to human cultural and economic development in the Neotropics (Trejo and Dirzo 2000; Fajardo et al. 2005). This relation has probably been held since the first humans populated the region several thousand years before present. It has attractive features for human use: (a) many of them are established in relatively flat landscapes, (b) their soils are often fertile due to a low rate of nutrient lixiviation and pedogenetic development, (c) they possess a marked rainfall seasonality that allows for an agricultural lifestyle based on short-cycle crops, (d) the forest low structural complexity and aerial biomass facilitates clearing, and (e) their drier climate limits the propagation of pathogens transmitted by mosquitoes (Ewel 1999; Murphy and Lugo 1986; Fajardo et al. 2005).

Human use of TDFs does not only come from land clearing for agricultural and urban development; 
undisturbed TDF fragments in the neotropics have been and still remain an important source of goods for communities that live around them. These forests are an important source of firewood, medicinal plants, animals for hunting as well as shade and fresh air to local peasants (Castillo et al. 2005; Balvanera and Castillo 2011; Bye 1995; Anaya et al. 2006). The use of tropical dry forest plant species ranges from food, beverages, condiments, wood for construction, firewood and medicinal herbal remedies (Bye 1995). Such direct use of resources from forests is not only restricted to rural areas. In north-western Venezuela, for example, communities living in impoverished urban areas frequently use neighbouring unprotected tropical dry forests remnants as a source of wood for construction and as a source of meat-iguanas, birds and rabbits-for their own consumption or for small-scale commercialization of bushmeat (Gonzalez 1980; Vera et al. 2009).

Historically, regional and national policies in land use have given greater weight to TDF as a source of agricultural and urban land than for conservation purposes. They are in fact considered now the most heavily utilized and disturbed ecosystem in the world, especially in the Americas (Janzen 1988; Sanchez-Azofeifa et al. 2005; Pennington et al. 2006; Ewel 1999; Gillespie et al. 2012; Stoner and Timm 2004; Hoekstra et al. 2005). PortilloQuintero and Sanchez-Azofeifa (2010) reported that only $44 \%$ of the original TDF is left in South, Meso and North America. Remnants of what were once large continuous tracts of forest cover in lowlands, and submontane areas are now highly fragmented across the subcontinent and under high anthropogenic pressure (Fig. 1).

Current governmental land management policies and regulations in the region are still based on the perception that TDFs are "useless" for biodiversity conservation, a misinformed position that translates in the absence of explicit policies for its preservation, management and use (Quesada et al. 2009; Rodríguez et al. 2008). Their current degree of legal protection is substantially lower than humid forests: while humid forests in protected areas account for $1,567,022 \mathrm{~km}^{2}(25 \%)$ of its total extent (Scharlemann et al. 2010), only $23,417 \mathrm{~km}^{2}(4.5 \%)$ of TDF in the

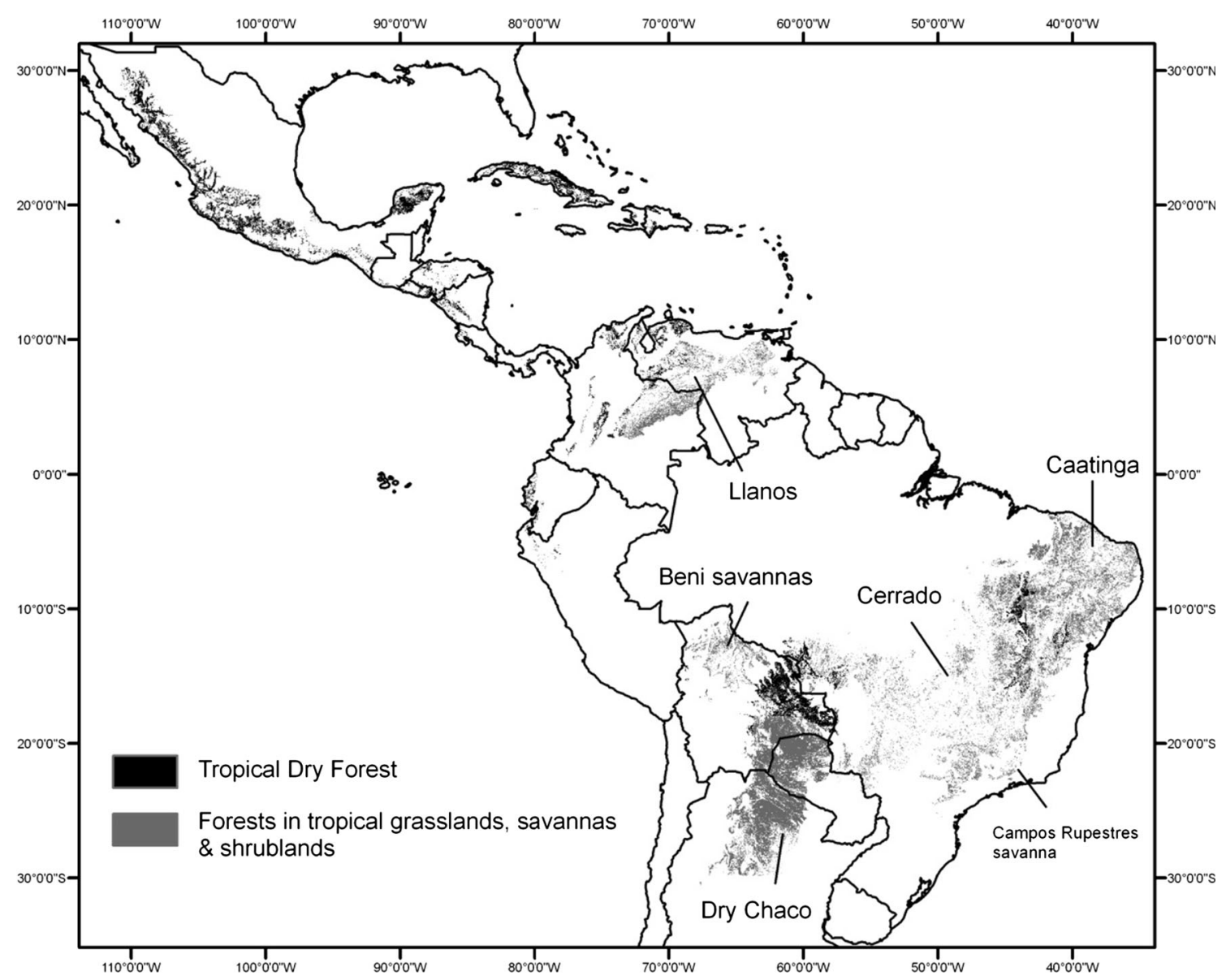

Fig. 1 Land cover map showing the extent and geographical distribution of neotropical dry forests (from Portillo-Quintero and Sanchez-Azofeifa 2010). The map also shows the extent and geographical distribution of seasonally dry forests in tropical and subtropical grassland, shrubland and savanna ecosystems 
Americas fall within any level of legal protection (PortilloQuintero and Sanchez-Azofeifa 2010). Consequently, high degrees of historic forest loss and degradation, persistent deforestation trends, and poor levels of protection are seriously threatening the sustainability of TDFs biodiversity and ecosystem services which remain, in fact, mostly unknown to the general public who live in these environments.

During the past decades, specialized groups in the tropical research community have made a tremendous effort in documenting the species richness, ecological complexity and carbon storage capacity of the ecosystem, fueling the discussion on its importance for long-term biodiversity and soil conservation, watershed stability and maintenance of ecosystem services for rural communities (e.g. Ewel 1977; Brown and Lugo 1982; Murphy and Lugo 1986; Janzen 1988; Mooney et al. 1995; Trejo and Dirzo 2000; Frankie et al. 2004; Pennington et al. 2006; PortilloQuintero and Sanchez-Azofeifa 2010; Dirzo et al. 2011; Sanchez-Azofeifa et al. 2005, 2014).

Current research and conservation programmes led by universities and NGOs are increasingly adding to the available information on TDF's biophysical, ecological and socioeconomic value for human livelihoods in the Americas. As relevant information at local- and regional-level increases, the tropical forest conservation community will move towards raising awareness on the importance of implementing conservation programs or making efforts to change land-use policies in TDF areas legally bound to be cleared for agricultural or urban development. However, the use of arguments based on single-species preservation (i.e. threatened umbrella species), its importance for local small-scale source of wood and meat, or even for ethnobotanical and cultural reasons, might not be enough to raise the interest of the political society at a municipal or national level or even to attract the attention of large conservation organizations that are focusing their efforts only on tropical rainforests. Clearly communicating the multiple ecosystem services that standing TDF can provide will be crucial for building an advocacy base for this ecosystem (Rodríguez et al. 2008).

In this paper, we reviewed the work in scientific literature to synthesize broad main biological and socioeconomic aspects of TDF that are held at different biogeographic scales. Scientific findings on TDFs compositional, structural and functional characteristics, as well as its historic and future value for watershed management in the Americas, are explored. We address three aspects of TDF: ACG (2013) Biodiversity uniqueness: its high degrees of endemism, diversity of plant life forms and ecophysiological types; Alvarez-Añorve et al. (2012) its significance in present and future regional carbon storage capacity and nutrient cycling balance, Alvarez et al. (2012) its importance for the landscape resilience to hydrological impacts of global change. Based on our review in the literature, we also discuss opportunities for research and conservation directed towards the sustainable management of Neotropical TDF landscapes.

\section{TDFs biodiversity uniqueness: high degrees of endemism, diversity of life forms and ecophysiological richness}

Tropical dry forests (TDFs) are a forest type that is physiologically and ecologically adapted to seasonal droughts. It exists in areas where the mean annual temperature is usually $>25{ }^{\circ} \mathrm{C}$ and total annual precipitation ranges from 700 to $2,000 \mathrm{~mm}$ (Sanchez-Azofeifa et al. 2005). In these ecoregions, at least $50 \%$ of its plant species show seasonal deciduousness and other adaptations, while animal species undergo behavioural and physiological strategies in order to cope with three or more months of limited or absent rainfall every year (Sanchez-Azofeifa et al. 2005; Mooney et al. 1995; Stoner and Timm 2011; Calvo-Alvarado et al. 2013).

Approximately $54 \%$ of the total TDF global coverage is located in the Americas (Miles et al. 2006). It encompasses a broad range of deciduous, semi-deciduous and evergreen plant species, with considerable variations in structure across the continent (Prado and Gibbs 1993; Pennington et al. 2004). In fact, the ecological definition of TDF considers savannas, riparian forests, coastlines and mangroves among the associated vegetation types that can occur within the matrix of TDF (Pennington et al. 2006; Sanchez-Azofeifa et al. 2005).

In general, TDFs are less diverse than wet or moist forests (Pennington et al. 2004; Gentry 1995). Lowland TDF have around 50-70 species $>2.5 \mathrm{~cm}$ diameter in 0.1 ha plots, while moist forests have $100-150$ species, wet evergreen forests have 150-200 species and, pluvial forests sustain 200-250 species in equivalent sample areas (Gentry 1995; Gillespie et al. 2000). In terms of structural features, such as number of lianas, number of trees and basal area, TDF differs relatively little from moist and wet forests (Gentry 1995). Gentry (1995) shows that TDF have the same average number of plants $>2.5 \mathrm{~cm}$ diameter at breast height (dbh) in 0.1 ha plots as do humid forests (370 vs. 373 ), the same number of trees $>10 \mathrm{~cm}$ dbh (65 vs. 64), the same number of lianas $>2.5 \mathrm{~cm}$ diameter ( $72 \mathrm{vs.} 68$ ) and only slightly lower basal area in $\mathrm{m}^{2} \mathrm{ha}^{-1}$ (34.7 vs. 40 ).

In the Americas, each major TDF region has a significant complement of endemic species and a few endemic genera, with TDF endemism levels in most regions tending to be higher than in adjacent moist forests (Linares-Palomino et al. 2011; Ceballos 1995; Santos et al. 2011; 
Sarkinen et al. 2011). Linares-Palomino et al. (2011) found that 12 of 23 neotropical TDF geographical nuclei have more that $20 \%$ of unique species (a proxy for level of endemism), being the highest nuclei Insular Caribbean $(77.5 \%)$ and Mexican Pacific $(65.5 \%)$ in the north and Equatorial Pacific $(47.1 \%)$ and Peruvian Inter-Andean Valley $(46.4 \%)$ in the South.

Additionally, as a response to limited water availability, TDF plant species show a more diverse range of morphological and functional adaptations than in any other tropical ecosystems, showing plasticity in the response to heat and water stress through water conservation, high photosynthetic capacity and temperature regulation (AlvarezAñorve et al. 2012). For example, tropical moist and wet forest include six major life forms; evergreen woody plants, deciduous woody plants, lianas, C3 epiphytes, CAM epiphytes and hemi-parasites, whereas TDF includes nine life forms: evergreen woody plants, deciduous woody plants ( $>40 \%$ of the woody species), sclerophyllous woody plants, succulent woody plants (including cacti), herbs, rosettes, lianas, CAM epiphytes and hemiparasites (Medina 1995).

In terms of animal diversity, although TDF has lower species richness than wet and moist forests, it maintains important levels of animal diversity. According to Ceballos (1995), the number of mammal species in TDF can range from 46 to 136 species compared to $76-150$ species in wet and moist forest locations, 200-270 species of birds in TDF as compared to $300-554$ in wet and moist forests, and 47-80 species of reptiles and amphibians as compared to $65-134$ species in wet and moist forests. Stoner and Timm (2011) indicate that animal species in TDF are characterized not just by enduring but thriving in a seasonal waterlimited environment through physiological adaptations (changes in body temperature, torpor and hibernation, water conservation, reproductive delay) and behavioural adaptations (dietary flexibility, long distance and short distance migration, local movements, timing of activity and/or foraging and seasonality of reproduction). TDFs are also repositories of vertebrate diversity in the neotropics because of their endemic species, which mainly consist of many small-sized vertebrates in the tropical dry forests of Mexico and the Chaco resulted from large-scale speciation events in the Pleistocene (Ceballos 1995).

Research on TDF has blossomed in the last decade, revealing not only the biological importance of these forests in terms of their highly endemic floras, but also important insights into the biogeography of this biome and the processes and factors that have apparently shaped the historical assembly of TDF species diversity (Hughes et al. 2013). In TDF, especially in areas of high species richness such as the Chamela region in Mexico, the Chiquitano tropical dry forests in Bolivia and the Brazilian Atlantic tropical dry forests, levels of high beta diversity imply that the spatial configuration of species assemblages, and the distribution of endemic species and phylogenetic relationships is complex (Pennington et al. 2006). High beta diversity in TDF suggests that the richness is not represented by one particular forest fragment or specific area, but it is dispersed among regional scales. Therefore, conservation of biodiversity in TDF is a challenging task that would encompass the conservation of forest fragments in diverse soils, topography and hydrological regimes within seasonal climates such as coastal, riparian, submontane and montane forests.

The landscape-level diversity that characterizes TDF makes it a very complex ecosystem in terms of the research that is needed to fully understand its ecological patterns and processes. Research using methods in landscape ecology are especially needed in human-dominated TDF landscapes as a step to suggest proper management schemes for its conservation at particular ecoregions or sites. Species composition and forest structure in TDF forests are also closely related to the land-use history of the landscape and the current anthropogenic pressure it withstands; however, its human dimensions are almost unexplored. Interdisciplinary research on this subject holds a great potential for understanding the ecological impacts of human social and economic geography in TDF landscapes.

\section{Significance in present and future regional carbon storage capacity and nutrient cycling balance}

Carbon storage in TDF biomass is estimated from measured organic matter in vegetation, soil and litterfall. A recent study published by Becknell et al. (2012) analysed the results from 188 TDF sites across Central and South America and reported aboveground living biomass estimates in mature TDF ranging from $39 \mathrm{Mg} \mathrm{ha}^{-1}$ in Chamela, Mexico to $334 \mathrm{Mg} \mathrm{ha}^{-1}$ in Guanacaste, Costa Rica. This accounts for approximately half of the storage capacity found in living aboveground biomass in humid forests which can range from 200 to $400 \mathrm{Mg} \mathrm{ha}^{-1}$ (Brown and Lugo 1982; Saatchi et al. 2011).

Additionally, studies by Holbrook et al. (1995) and Jaramillo et al. (2011) suggest that the majority of the carbon stock in TDF can be found in its soil. For example, average root biomass as a portion of total plant biomass has been reported greater in TDF $33.5 \%$ with a range of $8-50 \%)$ than in wet forests $(16 \%$ with a range of 5-33\%). Geoghegan et al. (2010) estimated carbon stocks of $375-405 \mathrm{Mg} \mathrm{ha}^{-1}$ in mature TDF of the Yucatan Peninsula (aboveground + soil) where $80 \%$ of the carbon is stored in the soil. In terms of annual total litterfall, TDFs average 4.5-6.0 $\mathrm{t} \mathrm{ha}^{-1}$ year $^{-1}$ with a range of 
2.9-10.1 $\mathrm{t} \mathrm{ha}^{-1}$ year $^{-1}$, which does not differ greatly from values found in moist and wet forests-5.2-14.0 $\mathrm{t} \mathrm{ha}^{-1}$ year $^{-1}$ - (Murphy and Lugo 1986; Lawrence 2005; Jaramillo et al. 2011). Annual tree diameter growth in TDF is 1-2 $\mathrm{mm}_{\text {year }}{ }^{-1}$ representing about half that of wet forests-2-5 mm year ${ }^{-1}$ _(Murphy and Lugo 1986).

Studies by Das et al. (2011), Campo et al. (2000, 2001), Lugo and Murphy (1986) and García-Oliva and Maass (1998) have found that TDFs are also highly efficient in the storage of phosphorous (P) - among the highest reported for tropical forests-, calcium $(\mathrm{Ca})$, nitrogen $(\mathrm{N})$, potassium $(\mathrm{K})$ and magnesium $(\mathrm{Mg})$ in the soil relative to atmospheric inputs and runoffs losses. In the TDF of the Pacific coast of Mexico, for example, Campo et al. (2001) found that runoff nutrient losses $(\mathrm{Ca}, \mathrm{K}, \mathrm{Mg})$ in stream water were significantly lower that the aboveground plant nutrient return. Das et al. (2011) found that late successional stage tropical dry forests had significantly higher $\mathrm{P}$ concentrations and inputs than open field or secondary forest stands. Interestingly, they found no significant differences between the older and younger secondary forests which means that even early to intermediate natural TDF regrowth (5-20 years old) has the capacity to recover important ecosystem functions and services.

This is especially important, because a characteristic that favours the conservation and restoration of TDF is the aboveground biomass accumulation at rapid rates that occur in secondary forests, appearing to close its maximum attainable biomass after approximately 3-5 decades (Kennard 2002; Powers et al. 2009; Becknell et al. 2012; Read and Lawrence 2003). Indeed, because of the predominance of sprouting species and wind-dispersed seeds, it has been assumed that tropical dry forests have the potential to recover its mature-stage biomass more quickly than do wet forests (Kennard 2002; Becknell et al. 2012; Murphy and Lugo 1986; Ewel 1977). However, since sprouting should introduce low genetic variation, achieving higher degrees of genetic variation (i.e. animal and wind-dispersed trees) in regenerated forests might need active restoration strategies such as fire prevention, suppression of wildlife hunting, and/or controlled burning and grazing to reduce biomass (Quesada et al. 2009; Powers et al. 2009). These strategies, for example, have successfully resulted in secondary forest regeneration in conservation areas of Northwestern Costa Rica through natural seed dispersal mechanisms (Janzen 1988; Stern et al. 2002).

De la Barreda-Bautista et al. (2010), by calculating rates of carbon flux emissions from Mexico tropical dry forests, estimated that total emissions from TDF conversion to agriculture and pasture (usually by slash and burn) can reach the order of $708 T_{\mathrm{g}}$ of carbon in the country, which is significantly higher than total carbon emissions estimated for tropical evergreen forests in
Mexico (569 $T_{\mathrm{g}}$ of carbon). However, scientific research indicates that TDF has the ability to recuperate its aboveground biomass at rapid rates with the potential of having, at intermediate successional stages (after few decades), at least half of a wet forest carbon storage capacity and restoring important part in the local and regional nutrient cycling balance. According to Becknell et al. (2012), if the world's TDFs were restored they whole ecosystem would comprise $22 P_{\mathrm{g}}$ of carbon in aboveground biomass. In the Americas, TDF restoration could potentially add $8 P_{\mathrm{g}}$ of carbon to the potential total ecosystem carbon stock.

\section{Its importance for landscape resilience to hydrological impacts of global change}

In the neotropics, a large fraction of the human population (approx. 90 million) lives in regions dominated by TDF (Fajardo et al. 2005; Holdridge 1967; Murphy and Lugo 1986). Many of these regions are currently water-stressed and additional pressures from population growth, land use and climate change will have significant implications for the future functioning of their natural and socioeconomic systems (Vose and Maass 1999; Montenegro and Ragab 2010; Farrick and Branfireun 2013). The high demand for water resources in TDF landscapes has translated into construction of new dams, irrigations systems, deviation of rivers and overuse of ground and superficial water resources.

To support the discussion on TDF importance in the regional hydrological balance in this study, a GIS analysis on the ecoregional location of major cities $(>50.000$ inhabitants) and freshwater natural and artificial reservoirs was carried out for neotropical countries was performed. GIS datasets of major cities and water reservoirs were obtained from ESRI datasets (via the Baruch Data Portal http://www.baruch.cuny.edu/geoportal/) and the Global Reservoir and Dam Database (GRanD) which compiles location of reservoirs with a storage capacity of more than $0.1 \mathrm{~km}^{3}$. Spatial data on the distribution of ecoregions were obtained from the WWF terrestrial ecoregions database. Results show that at least $44 \%$ of the cities of the neotropics are located within dry ecoregions, which includes TDF and also other ecosystems adapted to severe seasonal droughts (Table 1). Honduras has the largest percentage of its cities within dry ecoregions $(75 \%)$, followed by Mexico $(71 \%)$, Nicaragua (66\%), Venezuela (63\%), Bolivia (50\%), Peru (47\%), Colombia (30\%), Brazil (29\%) and El Salvador (25\%). We also found that at least $66 \%$ of water reservoirs and dams in the neotropics are located within these dry ecoregions, with Venezuela and Mexico having the largest percentage (85 and $84 \%$, respectively). 
Table 1 Proportion of major cities and national water reservoirs in countries with dry/xeric ecoregions

\begin{tabular}{|c|c|c|c|}
\hline & $\begin{array}{l}\% \text { Cities with } \\
\text { pop }>50 \mathrm{k} \text { in } \\
\text { dry/xeric } \\
\text { ecoregions }\end{array}$ & $\begin{array}{l}\% \text { National water } \\
\text { reservoirs in dry } \\
\text { forest/xeric } \\
\text { ecoregions }{ }^{\mathrm{b}, \mathrm{c}} \text { and } \\
\% \text { of these within } \\
\text { protected areas } \\
\text { under IUCN } \\
\text { Categories I-VI }\end{array}$ & $\begin{array}{l}\% \text { TDF loss } \\
\text { (From Portillo- } \\
\text { Quintero and } \\
\text { Sanchez-Azofeifa } \\
2010 \text { ) }\end{array}$ \\
\hline Honduras & 75 & $50(0)$ & \\
\hline Mexico & 71 & $84(3.4)$ & 71 \\
\hline Nicaragua & 67 & - & \\
\hline Venezuela & 63 & $85(51.7)$ & 74 \\
\hline Bolivia & 50 & $33(0)$ & 45 \\
\hline Peru & 47 & $40(0)$ & \\
\hline Colombia & 30 & $15(0)$ & 67 \\
\hline Brazil & 29 & $66(2.5)$ & 52 \\
\hline $\begin{array}{l}\text { El } \\
\text { Salvador }\end{array}$ & 25 & $33(0)$ & \\
\hline Ecuador & - & $75(0)$ & \\
\hline Total \% & 44 & $66(8.5)$ & \\
\hline
\end{tabular}

${ }^{a}$ Geolocation of major cities was obtained from ESRI datasets via http://www.baruch.cuny.edu

${ }^{\mathrm{b}}$ Geolocation of major water reservoirs and dams was obtained from the Global Reservoir and Dam database (GRanD) via http://www. gwsp.org/85.html

c Spatial data on the distribution of ecoregions were obtained from the WWF terrestrial ecoregions database (Available at: http://www. worldwildlife.org/science/data/item6373.html)

In general, land-use restrictions around water reservoirs and dams are meant to avoid sedimentation and pollution of major rivers, streams and water reservoirs from elevated nutrient levels due to fertilizers, animal waste and soil erosion. Given the importance of the protection of forests around water reservoirs and dams, we would expect an important number of forested lands within dry ecoregions being protected and managed through sustainable agricultural practices (i.e. areas with special land-use restrictions for agricultural practices and forest management). To explore whether such policies are held in regional land-use planning, we conducted a GIS analysis on the number of water reservoirs and dams in dry ecoregions that occur within protected areas. We used the World Database on Protected Areas (www.wdpa.org) which applies an internationally defined set of management categories, known as IUCN Protected Area Management Categories. According to Dudley (2008), the IUCN Category system defines differences in management approaches and identifies six categories of protected areas encompassing strict nature reserves and wilderness areas (Category I), national parks (Category II), natural monuments (Category III), habitat/ species management areas (Category IV), protected landscapes areas (Category V) and managed resource areas (Category VI).

Results show that only $8.46 \%$ of water reservoirs and dams in dry neotropical ecoregions are actually protected by any of the land-use management categories identified by the IUCN (Table 1). In fact, only 21 out of 248 water reservoirs in dry regions occur within protected areas: 15 in Venezuela (51\% of its reservoirs), 3 in Brazil (3.44\%) and 3 in Mexico (2.52\%). Protected areas were absent in all other countries with water reservoirs in dry ecoregions. Such lack of strict land-use restrictions around water reservoirs and dams in dry ecoregions is likely linked to the historic greater valuation given to dry lands for agricultural and urban expansion around principal populated areas, despite their value for hydrological balance and water provision to human settlements (Fajardo et al. 2005). However, these policies in land-use management in semiarid environments, which result in uncontrolled deforestation, have already taken its toll by leading to nitrogen and phosphorus pollution from farmland runoff, high turbidity and sedimentation in large water reservoirs located in dry ecoregions. Examples can be found in Lake Maracaibo and the Lake Valencia basins in Venezuela (Cressa et al. 1993; Jaffé et al. 1995; Lopez-Rojas and Bonilla-Rivero 2000; Alvarez et al. 2012; Salazar-Lugo 2009; Kiage and Walker 2008; Rivas et al. 2005). Around these lakes, TDF, once predominant, is now almost extinct (Portillo-Quintero et al. 2012; Rodríguez et al. 2008). The consequences have led to the greater use of treatment chemicals and increased dredging expenses to maintain fresh water sources unpolluted for human consumption. A well-studied example is the Tempisque River which drains the watershed that contains all the tropical dry forest of Costa Rica. In this river, the increasing and uncontrolled use of limited water resources for irrigation, human consumption, and tourism has reduced to $7 \%$ the original base flow of the driest month (April), jeopardizing the environmental flows, costal ecosystems and the supply of this valuable resource to society demands (Calvo-Alvarado et al. 2008; Guzmán and Calvo-Alvarado 2012). A similar example can be found in Brazil, where the largest irrigated perimeter in Latin America was established in the TDF region of the north of Minas Gerais. As a result of this project, conversion of TDF to croplands occurred at the margin of the São Francisco river, the second largest in the country, jeopardizing the navigability of the river due to sand banks resulting from sediment deposition.

Certainly, the lack of strict land-use restrictions around water reservoirs and dams in dry ecoregions threatens the sustainability of water provision to human settlements in the near future. The threat increases when climate change impacts are taken into account (Castellanos et al. 2008). According to a thorough analysis recently carried out by 
Meir and Pennington (2011) on the possible consequences of climate change on neotropical dry forest using a dynamic global vegetation model (DGVM), the estimated warming rates for TDF regions are consistent with, or slightly above, the global predicted means of approximately $2-4{ }^{\circ} \mathrm{C}$ warming by 2100 . The scenarios for regional alterations of rainfall are uncertain, and there is no clear global pattern emerging so far from the IPCC (2007). However, according to Bates et al. (2008), a 5-15\% reduction in soil moisture availability and runoff is expected by the late twenty-first century across much of tropical Latin America, and recent studies have also reported the occurrence of changes in the length of the dry and growing season during the past decades (SanchezAzofeifa et al. 2013; Magrin et al. 2007).

The importance of enhancing the protection status of TDF fragments and engaging in the sustainable management of TDF landscapes cannot be understated. This is necessary to avoid greater negative effects from soil erosion, pollution and sedimentation of rivers and streams and water reservoirs in the near future. Last and more importantly, it is imperative to understand that conservation of tropical dry forest will maintain and enhance ecosystems functions increasing the landscape resilience to hydrological impacts from global change (Castellanos et al. 2008). Although our understanding of these impacts is certainly limited and more research efforts are needed (Farrick and Branfireun 2013, 2014), detrimental consequences in terms of hydrological dynamics are expected to affect vast extensions of TDF environments in the region.

\section{Opportunities for its sustainable management}

The scientific literature has been clear in documenting the great value of TDF for biodiversity conservation and carbon sequestration. Its high degrees of endemism, diversity of plant life forms and ecophysiological types, as well as its carbon storage capacity and rapid regrowth are the main arguments for advocating conservation and/or sustainable management of many natural or disturbed TDF landscapes. However, tropical dry forests have multiple ecosystem services and uses, which are closely linked to human development. Their management and conservation needs to take these dimensions into consideration and go beyond the conservation its biodiversity and its potential for carbon storage capacity.

One of these aspects is related to its importance for the landscape resilience to hydrological impacts of global change and the sustainability of freshwater provision to a growing population in $44 \%$ of Latin American cities located in TDF ecoregions and home to more than 90 million people (Sect. 3). The impact of gains or losses in
TDF cover and productivity in these terms has not been thoroughly investigated and quantified. More research needs to be supported in this direction. It is also necessary that this aspect plays a greater role as a central argument for TDF conservation and sustainable management given its impacts on human livelihoods at all geographic scales.

Another interesting aspect is the potential for the sustainable management of TDF that has started to emerge from ecotourism. The scenic combination of bright blue seas and either the grey of TDF during the dry season or its lush green during the rainy season has drawn the attention of a growing tourism industry along the Pacific and Caribbean coasts (Balvanera and Castillo 2011; UN-WTO 2013, 2012). In these locations, ecotourism entrepreneurship is already generating important revenues from preserved local TDF, while creating direct jobs to local communities and enhancing the conservation value of natural TDF areas. At each destination, trips across natural trails and cultural landmarks inside and outside TDF national parks and biological reserves are often offered at price ranges of $\$ 60-\$ 120$ per person per day. In the state of Quintana Roo in Mexico, a half-day trip offered by the ecotourism company Alltournative S.A. includes a visit to archaeological landmarks, lagoons and Cenotes that are embedded in well-preserved TDF, with direct participation of people from various local Mayan communities. The tour includes experiencing ancient Mayan traditions and food. In this tour, a typical adult visitor can expend up to $\$ 150$ including the purchase of photos and souvenirs. More than 800 similar ecotourism and rural tourism companies operate in the states of Chiapas, Oaxaca, Michoacan, Puebla, Veracruz and Quintana Roo in Mexico, all located in dry forest ecoregions, with more than $\$ 20$ million investment by the federal government and the private sector (SECTUR 2004). One of the most visited areas by international and national tourists in Costa Rica, for example, is the Province of Guanacaste which includes tours to protected areas within the Tempisque Conservation Area and the Guanacaste Conservation area, mostly dominated by TDF. The Guanacaste Area has been receiving approximately 110,000 visitors annually in the past 2 years (2011-2012) especially during January and during the Semana Santa (Holy week) in April when the number of visitors reaches more than 12,000 visitors in each month (ACG 2013). Similar ecotourism potential is growing rapidly along tropical dry forest landscapes and conservation areas in Caribbean beach destinations in Cuba, the Dominican Republic, Jamaica, the Netherland Antilles and the Pacific coast of Colombia.

The level of priority placed on dry forest conservation by Caribbean islands due to increasing and potential income from tourism-related activities is evidenced by a higher coverage of tropical dry forests under protected 
status $(10.2 \%$ of current extent is protected) when compared to a $3.9 \%$ in countries of North, Central and South America with similar potential (Portillo-Quintero and Sanchez-Azofeifa 2010).

In general, advocacy for conservation and sustainable management of TDF will benefit from integrating its value in biophysical terms (e.g. carbon, biodiversity) with key ecosystem services and uses (e.g. its impact on hydrological dynamics and its potential for fostering ecotourism initiatives and entrepreneurship). By doing this, support and awareness could be wider and more effective in the long term, especially from national and local communities.

In parallel, a necessary step for governmental and nongovernmental environmental institutions is to keep investing in closing the information gap on the extent, distribution and conservation status of TDF. It is important to generate baseline information at geographic scales coupled with national and municipal decision-making. TDFs can be identified and studied based on a global definition or using the national or local definitions (e.g. tropical and subtropical dry forests, caatinga, agreste, mata acatingada, mesotrophic, mesophilous or mesophytic forest, semideciduous or deciduous forest, bosque caducifolio, bosque espinoso). Projects directed to provide baseline information should aim to include the geographic distribution of TDF plant and animal communities of early, intermediate and late successional stages, identifying hotspots of species diversity and endemism, information on the spatial distribution anthropogenic threats (deforestation maps) and ethnobotanical information (human-TDF interactions) from local to national scales.

Avoiding deforestation, forest degradation and pursuing active restoration of TDF should be taken into account as an opportunity for achieving national or regional objectives in biodiversity conservation and carbon sequestration in the neotropics. Given the ecosystem's capacity to accumulate belowground and aboveground biomass, support by the REDD+ programme (http://www.un-redd.org/), for example, should be accounted as an opportunity to increase awareness and foster long-term conservation programs in critically endangered tropical dry forests. Together, Mexico, Bolivia, Brazil, Colombia and Venezuela contain $93 \%$ of the tropical dry forests in continental areas and these countries are also all signatories of the Kyoto Protocol under the UN framework convention on climate change (UNFCCC) which legally binds them to emission reduction targets.

At the local level, research and conservation programs can promote TDF conservation by communicating its importance for watershed stability and climate change adaptation. Honduras, Ecuador, Venezuela, Mexico and Brazil, which have more than $50 \%$ of water reservoirs and dams in tropical dry forest areas, have already lost 74,75 ,
74,71 and $52 \%$ of their TDF extent, respectively (PortilloQuintero and Sanchez-Azofeifa 2010). This arises as an alarming fact, with consequences that haven't been quantified in terms of watershed stability, soil erosion and sedimentation for neotropical hydrological river and lakes network as well as in terms of climate change impacts and species extinction (Farrick and Branfireun 2013). Where applicable, ecotourism can be introduced as an argument for the conservation of TDF remnants with its potential for creating direct jobs to local communities and fostering awareness to visitors on its multiple ecosystem services.

\section{Conclusions}

The current extent of TDF in the neotropics is approximately $519,597 \mathrm{~km}^{2}$, but only $23,417 \mathrm{~km}^{2}(4.5 \%)$ is legally preserved for conservation purposes (Portillo-Quintero and Sanchez-Azofeifa 2010). That means that almost all remnants that are scattered through the neotropics remain in privately or communal owned land, probably waiting to be cleared for agricultural production, since the most tangible benefits associated with a TDF remnant are agricultural and pastoral goods are derived from its transformation (Balvanera and Castillo 2011). In most of the cases, the alternative of sustainable management or preservation might not even be on the table.

The fundamental assumption is that other tropical forests ecosystems are negligible outside the tropical rainforests; and this has driven the amount of scientific literature available since 1945 (Sanchez-Azofeifa et al. 2013). But blossoming scientific research on biophysical and socioeconomic aspects of TDF in the past years have generated enough information to counteract with the perception that these are negligible and not worthy of preservation. There are enough arguments for governmental and non-governmental organizations to promote conservation policies for TDF use and management at any biogeographic scale, and these can all be supported by scientific, social, economic and ethical considerations. We consider that findings on its unique biodiversity, its potential in present and future carbon sequestration and its role in the provision of ecosystem services directly related to human livelihoods are filled with strong arguments that can be used for introducing changes in land-use regulations and/or promoting conservation programs at the scale of a watershed, ecoregion or at the national level. In terms of importance in providing soil, water-dynamics, climate and air quality regulating services, TDF has direct influence in at least $44 \%$ of the cities of the neotropics and at least $66 \%$ of water reservoirs and dams of neotropical countries, are located within dry ecoregions, with Venezuela and Mexico having the largest percentage (85 and $84 \%$, 
respectively). This pattern indicates that the conservation of the quality of freshwater sources for human consumption in the neotropics is and will be directly dependent on environmentally sustainable land management of TDFdominated landscapes.

Governmental and non-governmental environmental institutions have an important role on clearly communicating the multiple ecosystem services that standing tropical dry forests can provide to all local, national and regional stakeholders. Multidisciplinary research and technical teams need to work closely with official institutions in order to identify potential conservation areas where preservation of TDF remnants and natural restoration can be justified not only in terms of its biological diversity and its potential for carbon sequestration, but also for its value for the protection of freshwater sources and its potential for ecotourism. The effective communication of these multiple services can increase the support and awareness of a wider audience in the governmental and non-governmental sector which could secure the success of conservation and sustainable management strategies in the long term.

Acknowledgments This work was carried out with the aid of a grant from the Inter-American Institute for Global Change Research (IAI) CRN3 025 which is supported by the US National Science Foundation (Grant GEO-1128040). Logistical support by the University of Alberta is acknowledged. We thank Geraldo Wilson Fernandes for comments on early versions of the manuscript.

\section{References}

ACG (2013) Informe de Visitación 2012. Programa de Ecoturismo Area de Conservacion Guanacaste. http://www.acguanacaste. accr

Alvarez M, Aru R, Barrero M, González E, González Y, Sepúlveda G (2012) Estudio biogeoquímico del embalse Suata, Venezuela, de acuerdo al contenido metálico de sus sedimentos de fondo, aguas y peces. ACI: $3(1): 103-114$

Alvarez-Añorve M, Quesada M, Sanchez-Azofeifa A, Avila-Cabadilla L, Gamon J (2012) Functional regeneration and spectral reflectance of trees during succession in a highly diverse tropical dry forest ecosystem. Am J Bot 99(5):816-826. doi:10.3732/ajb.1100200

Anaya F, Barbosa R, Sampaio C (2006) Sociedade e biodiversidade na mata seca mineira. Unimontes Cientifica 8:35-41

Balvanera, P, Castillo A, Martínez-Harms J (2011) Ecosystem services in seasonally dry tropical forests. In: Dirzo R, Young H, Mooney H, Ceballos G (eds), Seasonally dry tropical forests: ecology and conservation, pp 259-278. Island Press, London, UK, 408 p. ISBN: 9781597267038

Bates BC, Kundzewicz ZW, Wu S, Palutikof JP (eds) (2008) Climate change and water. Technical Paper of the intergovernmental panel on climate change Geneva: IPCC Secretariat

Becknell JM, Kissing Kucek L, Powers JS (2012) Aboveground biomass in mature and secondary seasonally dry tropical forests: a literature review and global synthesis. For Ecol Manag 276:88-95. doi:10.1016/j.foreco.2012.03.033

Brown S, Lugo A (1982) The storage and production of organic matter in tropical forests and their role in the global carbon cycle. Biotropica 14:161-187
Bye R (1995) Ethnobotany of the Mexican tropical dry forests. In: Bullock SH, Mooney HA, Medina E (eds) Seasonally dry tropical forests. Cambridge University Press, Cambridge, pp 423-433

Calvo-Alvarado J, Jiménez J, González E, Pizarro F, Jiménez A (2008) Estimación preliminar del caudal ambiental en el río Tempisque, Costa Rica: El enfoque hidrológico con pocos datos Kurú. Rev For (Costa Rica) 5(13):1-10

Calvo-Alvarado J, Sanchez-Azofeifa A, Portillo-Quintero C (2013) Neotropical seasonally dry forests. In: Levin S (ed) Encyclopedia of biodiversity, 2nd edn. Academic Press, pp 488-500. ISBN: 9780123847195

Campo J, Maass JM, Jaramillo y VJ, Martínez-Yrízar A (2000) Calcium, potassium, and magnesium cycling in a Mexican tropical dry forest ecosystem. Biogeochemistry 49:21-36. doi:10.1023/A:1006207319622

Campo J, Maass M, Jaramillo VJ, Martínez-Yrízar A, Sarukhán J (2001) Phosphorus cycling in a Mexican tropical dry forest ecosystem. Biogeochemistry 53:161-179. doi:10.1023/A: 1010663516029

Castellanos E, McClain M, Alvarez M, Brklacich M, Calvo-Alvarado J, Coutinho H, Jiménez-Osornio J, Schellenberg M (2008) Conservation to sustain ecological processes and services in landscapes of the Americas. In: Tiessen H, Stewart J (eds) Applying ecological knowledge to landuse decisions. (SCOPE) Scientific Committee on Problems of the Environment IAI, the Inter-American Institute for Global Change Research, and IICA, the Inter-American Institute for Cooperation on Agriculture, pp 23-33

Castillo A, Magaña A, Pujadas A, Martínez L, Godínez C (2005) Understanding the interaction of rural people with ecosystems: a case study in a tropical dry forest of Mexico. Ecosystems 8:630-643. doi:10.1007/s10021-005-0127-1

Ceballos G (1995) Vertebrate diversity, ecology and conservation in neotropical dry forest. In: Mooney HA, Bullock SH, Medina E (eds) Seasonally tropical forests. University of Cambridge Press, Cambridge, p 450

Cressa CE, Vásquez E, Zoppi J, Rincón J, López C (1993) Aspectos generales de la limnología en Venezuela. Interciencia 18:237-248

Das R, Lawrence D, D'Odorico P, DeLonge M (2011) Impact of land use change on atmospheric $\mathrm{P}$ inputs in a tropical dry forest. J Geophys Res 116:G01027. doi:10.1029/2010JG001403

De la Barreda-Bautista B, López-Caloca A, Couturier S, SilvánCárdenas JL (2010) Tropical dry forests in the global picture: the challenge of remote sensing-based change detection in tropical dry environments. In: Carayannis E (ed) Planet earth 2011: global warming challenges and opportunities for policy and practice, pp 231-256

Dirzo R, Young H, Mooney H, Ceballos G (2011) Seasonally dry tropical forests: ecology and conservation. Island Press, London, 408 p. ISBN: 9781597267038 , pp 259-278

Dudley N (2008) Guidelines for applying protected area management categories IUCN/WCPA/Regional Council for the Environment of Junta de Andalucía/Fundacion Biodiversidad. http://www. dataiucnorg/dbtw-wpd/edocs/paps-016pdf

Ewel J (1977) Differences between wet and dry successional tropical ecosystems. Geo Eco Trop 1:103-117

Ewel J (1999) Natural systems as models for the design of sustainable systems of land use. Agrofor Syst 45:1-21

Fajardo L, González V, Nassar J, Lacabana P, Portillo C, Carrasquel F, Rodríguez JP (2005) Tropical dry forests of Venezuela: characterization and current conservation status. Biotropica 37(4):531-546. doi:10.1111/j.1744-7429.2005.00071.x

Farrick KK, Branfireun BA (2013) Left high and dry: a call to action for increased hydrological research in tropical dry forests. Hydrol Process. doi:10.1002/hyp.9935 
Farrick KK, Branfireun BA (2014) Infiltration and soil water dynamics in a tropical dry forest: it may be dry but definitely not arid. Hydrol Process. doi:10.1002/hyp.10177

Frankie GW, Mata A, Vinson SB (2004) Biodiversity conservation in Costa Rica learning the lessons in a seasonal dry forest. University of California Press, Berkeley, pp 48-66. ISBN: 9780520241039

García-Oliva F, Maass JM (1998) Efecto de la transformación de la selva a pradera sobre la dinámica de los nutrientes en un ecosistema tropical estacional en México. Boletín de la Sociedad Botánica de México 62:39-48

Gentry AH (1995) Diversity and floristic composition of neotropical dry forests. In: Mooney HA, Bullock SH, Medina E (eds), Seasonally tropical forests. University of Cambridge Press, Cambridge, p 450

Geoghegan J, Lawrence D, Schneider L, Tully K (2010) Accounting for carbon in models of land use and implications for payments for environmental services: an application to SYPR. Reg Environ Change. doi:10.1007/s10113-010-0111-y

Gillespie TW, Grijalva A, Farris CN (2000) Diversity, composition, and structure of tropical dry forests in Central America. Plant Ecol 147:37-47

Gillespie T, Lipkin B, Sullivan L, Benowitz D, Pau S, Keppel G (2012) The rarest and least protected forests in biodiversity hotspots. Biodivers Conserv. doi:10.1007/s10531-012-0384-1

Gonzalez E (1980) Estudio preliminar de la vegetacion del bosque xerofilo de la region de Las Peonias (Estado Zulia, Venezuela). Bol Centro Invest Biol 14:83-99

Guzmán I, Calvo-Alvarado J (2012) Water resources of the Upper Tempisque river watershed, Costa Rica. Tecnología en Marcha 25(4):63-70

Hoekstra J, Boucher T, Ricketts T, Roberts C (2005) Confronting a biome crisis: global disparities of habitat loss and protection. Ecol Lett 8:23-29. doi:10.1111/j.1461-0248.2004.00686.x

Holbrook M, Whitbeck J, Mooney H (1995) Drought responses of neotropical dry forest trees. In: Mooney HA, Bullock SH, Medina E (eds) Seasonally tropical forests. University of Cambridge Press, Cambridge, p 450

Holdridge L (1967) Life zone ecology tropical science center. San Jose, Costa Rica, p 206

Hughes C, Pennington T, Antonelli A (2013) Neotropical plant evolution: assembling the big picture. Bot J Linn Soc 171(1):1-18. doi:10.1111/boj.12006

IPCC (2007) Climate change 2007: the physical science basis. In: Solomon S, Qin D, Manning $M$ et al (eds) Contribution of working group I to the fourth assessment report of the intergovernmental panel on climate change. Cambridge University Press, Cambridge

Jaffé R, Espino R, Benitez F, Gardinali PR (1995) Pollution chronology of Lake Valencia Venezuela. Bull Environ Contam Toxicol 54:930-936

Janzen DH (1988) Tropical dry forests: the most endangered major tropical ecosystem. In: Wilson EO (ed) Biodiversity. National Academy Press, Washington, DC, pp 130-137

Jaramillo V, Martinez-Yrizar A, Sanford R (2011) Primary productivity and biogeochemistry of seasonally dry tropical forests, pp 18-36 In: Dirzo R, Young H, Mooney H, Ceballos G (eds) Seasonally dry tropical forests: ecology and conservation, pp 210-235. Island Press, London, UK, 408 p. ISBN: 9781597267038

Kennard D (2002) Secondary forest succession in a tropical dry forest: patterns of development across a 50-year chronosequence in lowland Bolivia. J Trop Ecol 18:53-66

Kiage LM, Walker ND (2008) Using NDVI from MODIS to monitor duckweed bloom in Lake Maracaibo, Venezuela. Water Resour Manag. doi:10.1007/s11269-008-9318-9
Lawrence D (2005) Regional-scale variation in litter production and seasonality in the tropical dry forests of southern Mexico. Biotropica 37(4):561-570. doi:10.1111/j.1744-7429.2005. 00073.x

Linares-Palomino R, Oliveira-Fiho A, Pennington T (2011) Neotropical seasonally dry forests: diversity, endemism, and biogeography of woody plants, pp 18-36 In: Dirzo R, Young H, Mooney $\mathrm{H}$, Ceballos G (eds) Seasonally dry tropical forests: ecology and conservation, pp 210-235. Island Press, London, UK, 408 p. ISBN: 9781597267038

Lopez-Rojas H, Bonilla-Rivero A (2000) Anthropogenically induced fish diversity reduction in Lake Valencia Basin, Venezuela. Biodivers Conserv 9:757-765. doi:10.1023/A:1008945813101

Lugo AV, Murphy PG (1986) Nutrient dynamics of a Puerto Rican subtropical dry forest. J Trop Ecol 2:55-72

Magrin G, Gay García C, Cruz Choque D, Giménez JC, Moreno AR, Nagy GJ, Nobrand C, Villamizar A (2007) Latin America/ climate change 2007: impacts, adaptation and vulnerability. In: Parry ML, Canziani OF, Palutikof JP, van der Linden PJ, Hanson CE (eds) Contribution of working group II to the fourth assessment report of the intergovernmental panel on climate change. Cambridge University Press, Cambridge, pp 581-615

Medina E (1995) Diversity of life forms plants in neotropical dry forest. In: Mooney HA, Bullock SH, Medina E (eds) Seasonally tropical forests. University of Cambridge Press, Cambridge, p 450

Meir P, Pennington RT (2011) Climate change and seasonal dry tropical forests In: Dirzo R, Young H, Mooney H, Ceballos G (eds) Seasonally dry tropical forests: ecology and conservation. Island Press, London, pp 294-315. ISBN: 9781597267038

Miles L, Newton A, DeFries R, Ravilious C, May I, Blyth S, Kapos V, Gordon J (2006) A global overview of the conservation status of tropical dry forests. J Biogeogr 33:491-505. doi:10.1111/j. 1365-2699.2005.01424.x

Montenegro A, Ragab R (2010) Hydrological response of a Brazilian semi-arid catchment to different land use and climate change scenarios: a modelling study. Hydrol Process 24:2705-2723. doi:10.1002/hyp.7825

Mooney HA, Bullock SH, Medina E, (1995) Introduction. In: Mooney HA, Bullock SH, Medina E (eds) Seasonally dry tropical forests. Cambridge University Press, Cambridge, p 450

Murphy PG, Lugo AE (1986) Ecology of tropical dry forest. Ann Rev Ecol Syst 17:67-88

Pennington RT, Lavin M, Prado DE, Pendry CA, Pell S, Butterworth CA (2004) Historical climate change and speciation: neotropical seasonally dry forest plants show patterns of both tertiary and quaternary diversification. Philos Trans R Soc Biol Sci 359:515-538. doi:10.1098/rstb.2003.1435

Pennington T, Lewis G, Ratter J (2006) A overview of the plant diversity, biogeography and conservation of neotropical savannas and seasonally dry forests: plant diversity, biogeography and conservation. In: Pennington $\mathrm{T}$, Lewis G, Ratter J (eds) Neotropical savannas and seasonally dry forests: plant diversity, biogeography and conservation. CRC Press, Boca Raton, FL, p 484. ISBN: 9780849329876

Portillo-Quintero C and Sanchez-Azofeifa GA (2010) Extent and conservation of tropical dry forests in the Americas. Biol Conserv 143(1):144-155. doi:10.1016/j.biocon.2009.09.020

Portillo-Quintero C, Larreal J, Gonzalez I, Sanchez A, Valbuena C (2012) Forest cover and deforestation patterns in the Northern Andes (Lake Maracaibo Basin): a synoptic assessment using MODIS and Landsat imagery. Appl Geogr 35:152-163. doi:10. 1016/j.apgeog.2012.06.015

Powers JS, Becknell JM, Irving J, Pérez-Aviles D (2009) Diversity and structure of regenerating tropical dry forests in Costa Rica: 
geographic patterns and environmental drivers. For Ecol Manag 285(6):959-970. doi:10.1016/j.foreco.2008.10.036

Prado DE, Gibbs PE (1993) Patterns of species distributions in the dry seasonal forests of South America. Ann Mo Bot Garden 80:902-927

Quesada M, Sanchez-Azofeifa GA, Alvarez-Anorve M, Stoner K, Avila-Cabadilla L, Calvo-Alvarado J, Castillo A, Espiritu-Santo M, Fagundes M, Fernandes G, Gamon J, Lopezaraiza-Mikel M, Lawrence D, Morellato P, Powers J, Neves F, Rosas-Guerrero V, Sayago R, Sanchez-Montoya G (2009) Succession and management of tropical dry forests in the Americas: review and new perspectives. For Ecol Manag 258:1014-1024. doi:10.1016/j. foreco.2009.06.023

Read L, Lawrence D (2003) Recovery of biomass following shifting cultivation in dry tropical forests of the Yucatan. Ecol Appl 13:85-97. doi:10.1890/1051-0761(2003)013[0085:ROBFSC]2. $0 . \mathrm{CO} ; 2$

Rivas Z, Sanchez J, Troncone F, Marquez R, Ledo De Medina H, Colina M (2005) Nitrógeno y fósforo totales de los ríos tributarios al sistema lago de Maracaibo, Venezuela. Interciencia 34(5):308-314

Rodríguez JP, Nassar J, Rodríguez-Clark K, Zager I, PortilloQuintero CA, Carrasquel F, Zambrano S (2008) Tropical dry forests in Venezuela: assessing status, threats and future prospects. Environ Conserv 35:311-318. doi:10.1017/ S0376892908005237

Saatchi SS, Harris NL, Brown S, Lefsky M, Mitchard ETA, Salas W, Zutta BR, Buermann W, Lewis SL, Hagen S, Petrova S, White L, Silman M, Morel A (2011) Benchmark map of forest carbon stocks in tropical regions across three continents. Proc Natl Acad Sci 108:9899-9904. doi:10.1073/pnas.1019576108

Salazar-Lugo R (2009) Current state of knowledge of the concentrations of cadmium, mercury and lead from aquatic organisms of Venezuela. REDVET Revista Electrónica de Veterinaria 10(11). www.veterinariaorg/revistas/redvet

Sanchez-Azofeifa A, Portillo-Quintero C, Wilson-Fernandes G, Stoner K, Shimizu T (2013) The policy process for land use/ cover change and forest degradation in the semi-arid Latin American/Caribbean region: perspectives and opportunities. A literature review prepared for the Inter-American Development Bank. http://www.tropi-dryeasualbertaca/pdf/Papers/IDB-2011White_paper.pdf

Sanchez-Azofeifa A, Powers J, Fernandes GW, Quesada M (2014) Tropical dry forests in the Americas: ecology, conservation and management. CRC Press, USA, p 538. ISBN: 9781466512009

Sanchez-Azofeifa A, Kalacska M, Quesada M, Calvo-Alvarado J, Nassar J, Rodriguez J (2005) Need for integrated research for a sustainable future in tropical dry forests Conserv Biol 19(2):1-2. doi:10.1111/j.1523-1739.2005.s01_1.x
Santos JC, Leal IR, Almeida-Cortez JS, Fernandes GW, Tabarelli M (2011) Caatinga: the scientific negligence experienced by a dry tropical forest. Trop Conserv Sci 4(3):276-286

Sarkinen TE, Marcelo-Pena JL, Yomona AD, Simon MF, Pennington T, Hughes CE (2011) Underestimated endemic species diversity in the dry inter-Andean valley of the Río Marañón, northern Peru: an example from Mimosa (Leguminosae, Mimosoideae). Taxon 60(1):139-150

Scharlemann JPW, Kapos V, Campbell A, Lysenko I, Burgess ND, Hansen M, Gibbs H, Dickson B, Miles L (2010) Securing tropical forest carbon: the contribution of protected areas to REDD. Oryx 44:352-357. doi:10.1017/S0030605310000542

SECTUR (2004) Acuerdan impulsar el ecoturismo y el turismo rural. Boletines de Prensa 109/04 SECTUR Mexico, DF. http://www. sectur.gob.mx

Stern M, Quesada M, Stoner KE (2002) Changes in composition and structure of a tropical dry forest following intermittent cattle grazing. Rev Biol Trop 50:1021-1034

Stoner K, Timm R (2004) Tropical dry forest mammals of Palo Verde: ecology and conservation of a changing landscape. In: Frankie GW, Mata A, Vinson SB (eds) Biodiversity conservation in Costa Rica learning the lessons in a seasonal dry forest. University of California Press, Berkeley, pp 48-66. ISBN: 9780520241039

Stoner K, Timm R (2011) Seasonally dry tropical forest mammals: adaptations and seasonal patterns. In: Dirzo $\mathrm{R}$, Young $\mathrm{H}$, Mooney H, Ceballos G (eds) Seasonally dry tropical forests: ecology and conservation, pp 100-121. Island Press, London, 408 p. ISBN: 9781597267038

Trejo I, Dirzo R (2000) Deforestation of seasonally dry tropical forest: a national and local analysis in Mexico. Biol Conserv 94:133-142. doi:10.1016/S0006-3207(99)00188-3

UN-WTO (2012) Panorama OMT del Turismo International Organizacion Mundial del Turismo. http://www.unwto.org

UN-WTO (2013) Press release: International tourism to continue robust growth in 2013. http://media.unwto.org

Vera A, Martínez M, Ayala Y, Montes S, González A (2009) Florística y fisonomía de un matorral xerófilo espinoso intervenido en Punta de Piedras, Municipio Miranda, Estado Zulia, Venezuela. Rev Biol Trop 57(1-2):271-281

Vose JM, Maass JM (1999) A comparative analysis of hydrologic responses of tropical deciduous and temperate deciduous watershed ecosystems to climatic change. In: Aguirre-Bravo C, Franco CR (eds) North American science symposium: toward a unified framework for inventorying and monitoring forest ecosystem resources; 1998 November 2-6; Guadalajara, Mexico. Proceedings RMRS-P-12. Fort Collins, CO: U.S. Department of Agriculture, Forest Service, Rocky Mountain Research Station, pp 292-298 